\title{
Design of the diploma program of physical education and sports specialization of the management of health clubs in the light of quality standards
}

\author{
DR. Abdul Hamid Saleh Ahmed Mahmoud \\ DR.Akrami Abdul Ati Mabad El Gamal
}

\section{Introduction and Research Problem:}

The human resources force is the basis and input of the various nations, to achieve wealth and success of the process of community development in a changing and growing global framework, and the competition and high quality of university and higher education, especially with the increase in the enrollment of institutions and programs of higher education, university and alumni. The University is demanding more than ever to work on human investment with the maximum possible capacity, through the development of human skills and the development of new disciplines suited to the requirements of the age while taking care to graduate cadres and creative minds and competencies and expertise capable of innovation and creativity Those necessary to deal with all the developments and changes taking place in the era of skills. $(7: 15,6)$

With the rapid increase in knowledge, business changes and requirements, and the composition and distribution of the workforce changes. These changes include the decrease in the need for unskilled labor, the change in business technology, the increase in the service and information professions, the change in the role of women in work, and the continuous increase in unemployment among young people who do not have labor market requirements. These changes lead to the need to plan professional preparation programs to cope with these changes. The university, when preparing young people for careers, does not prepare them for careers for life. It is important to develop their curricula and study and training programs to cope with the ongoing changes in the business and the labor market. Hence the importance of studying the academic preparation of the Sport for All Program for the elderly as it is responsible for carrying out the activities carried out by the elderly of all kinds $(1: 27,25)$

Health clubs have become one of the most important fields of investment in sports. Their development has become a necessary necessity of life. The use of modern technology and scientific progress show the importance of practicing sports activities in the lives of individuals and peoples. This development influenced the ways and methods of thinking in general terms. The system of education and leisure time in our Egyptian society where health clubs have become an urgent necessity and a necessity in the lives of individuals and in educational and educational institutions. (124: 4)

Many of the societies that pioneered health clubs, with their philosophies and systems, were interested in preparing health club managers to meet the needs of 
these communities. Thomas Plummer noted that the manager of the health club must have some leadership qualities so that he can lead people towards To achieve successful work, first he needs to have knowledge and therefore must be familiar with how to manage the work of the health club and how to manage employees in different jobs, in addition to having knowledge about health and nutrition

Due to the importance of the role of the director of the health club in achieving the objectives of the health club varied, it became necessary to prepare managers and management of the health club through specialized academic institutions. Therefore, the researchers are trying through this research to design the program of management diploma of health clubs in light of quality standards.

\section{Search Aims:}

Design of the diploma program of physical education and sports specialization of the management of health clubs in the light of quality standards related studies:

- Terry \& Denise (2014) (16) conducted a study entitled "Multivariate Exploratory Study to Review and Review Organizational Obligations in Health Sports Clubs". The study aimed at analyzing organizational variables in health sports clubs. 17) health club, and the most important results identified eight variables by managers to attract customers and maintain them variables related to the administrative aspects and the level of administrative service provided to them and variables related to the social aspects and also variables related to the various aspects of entertainment, including the modernity of devices and Diversity and variety of activities practiced within the health club and other aspects that attract customers and ensure the continuation of their practice Habbah Ahmad Bastawi Ahmed (2013) (11) a study entitled Total Quality Management as an input to improve the administrative performance of health clubs in Alexandria "The study aims to develop the administrative performance of the health clubs in Alexandria Governorate in the light of TQM, by identifying the extent of commitment The management's belief in the management of the total quality, the extent to which the management focused on the client, the availability of effective management of the human element in the health club, the availability of the training system for health club employees, the availability of the integrated health information system, The researcher used the descriptive approach to follow the survey method for the nature of the study. The study sample was chosen from (Health Club Manager, Assistant Manager, Supervisors, Sports Trainers, Massage Specialists, Receptionists, Workers The basic sample of the study was 230 samples and the sample was 50 samples from outside the basic research sample. The researcher used the questionnaire as a data collection tool and the researcher concluded that the management of the health club And the wishes of the beneficiary one of its responsibilities, there is no effective system to study complaints and inquiries of subordinates and their 
degree of satisfaction, the management of the health club does not improve and develop the services and activities and programs provided to the beneficiaries, there is no system to assess the performance of individuals, and is not using specialized experts to identify training needs, The health club methodology to determine their needs of modern technologies.

- Shaima Mohammed Yahya (2012) (4) a study entitled "Effective management of the human element and its role in the quality of performance and satisfaction of beneficiaries in health clubs" The study aims to 1 - identify effective management systems for the human element in the health clubs in question 2 The quality of the performance of the employees 3 - measuring the satisfaction of the beneficiaries of the quality of services provided 4 - determine the relationship between the quality of human performance and satisfaction of beneficiaries, and used the descriptive method, analytical and case study and comparison between the community and sample research, the research community consists of hotels in the Arab Republic of Egypt, club The study was chosen as a representative of the community in a deliberate manner. It consisted of 14 hotels. The permanent beneficiaries were randomly selected from the participating members of the two sexes, as well as the beneficiaries of the Egyptians and foreigners. The researcher determined the objectives of effective management of the human element accurately To the existence of a clear and approved plan to meet the needs of employees or beneficiaries of the health club from the administrative point of view, the management of the health club to clarify the functional description of various work and in the light of clear criteria allow them to select competencies Of the human elements that have the skill, qualification and standards.

- The study aims at building a proposed organizational structure for the management of health clubs in tourist villages by identifying the objectives of health clubs in the tourist villages and policies. And the basic functions of health clubs in tourist villages and jobs in sections of health clubs. The researcher used the descriptive method in the survey method to suit the nature of the study. The sample of the research was 100 health clubs in the tourist villages in the Red Sea, 300 of the research community 300 health clubs in the tourist villages in Red Sea Governorate, the basic sample for workers within the health clubs 95 director 85 supervisors 76 marketing specialists. The researcher used the questionnaire as a means of data collection, and the researcher reached a proposed organizational structure for the management of health clubs in tourist villages

Glena Bower (2011) (15) conducted a study entitled "The reluctance of members to continue training in health sports clubs." The study aimed at identifying the reasons for the reluctance of trainees or clients to continue to participate in health dew. The number of members of the community of 10 different health clubs levels. The most important results were as follows: 1 . The trainee was quick to obtain the results of the training quickly. 2. The lack of 
sports culture among some customers, Inside the health club does not contain a ton atmosphere So what drives customers to boredom and non-continuity 4 Different cultures between customers who are reluctant to the health club feel some customers not satisfied, which leads some to reluctance and not to continue to exercise in the health club

\section{Search proceedings}

Research Methodology: The researchers used the descriptive approach. Research Community: The research community is comprised of graduate students from the Faculty of Physical Education for Boys at Helwan University, specializing in the training and management of health clubs for the academic years 2015-2014 (2016: 2015, 2016: 2017). Sample of the research: The researchers randomly selected the sample of the sample. The sample size (282) among the graduates of the Bachelor of Physical Education program reached two sports training and sports management divisions since the academic year 2014 until 2017. The sample size reached (174) Graduated students for three years, working in health clubs (managers, trainers) and the size of the sample (90) individuals.

\section{Data collection tools}

The researchers used the following data collection tools: - Application form of the Diploma of Management of Health Clubs "Annex 2" and follow the researcher in building on the following steps - Identification of six axes reached by the researchers through the collection of information through access to reference studies and specialized references, Annex (3).

The researchers presented the proposed topics to (11) experts in the field of sports management, health clubs and quality facility (1), to express their opinion on the suitability and adequacy of the design of the program form. The researcher agreed to stay on the axes that have 85\% ) And more, Table (1).

\section{Table (1) Percentage of expert opinions towards the preliminary picture of} the proposed program axes $(n=11)$

\begin{tabular}{|c|c|c|c|c|}
\hline p & Program axes & suitable & inappropriate & percentage \\
\hline 1 & $\begin{array}{l}\text { Objectives of the proposed management } \\
\text { program for health clubs }\end{array}$ & 1. & 1 & $\% 9 \cdot, 9$ \\
\hline \multirow[t]{4}{*}{ r } & $\begin{array}{l}\text { Targeted Learning Outcomes for the proposed } \\
\text { Health Clubs Management Diploma Program } \\
\text {.Knnowledge and understanding }\end{array}$ & \multirow[t]{4}{*}{11} & \multirow[t]{4}{*}{. } & \multirow[t]{4}{*}{$\% 1 \cdots$} \\
\hline & بMental & & & \\
\hline & ج.Professional and practical skills & & & \\
\hline & .-General and movable skills & & & \\
\hline$r$ & $\begin{array}{l}\text { Contents of the Proposed Health Clubs } \\
\text { Management Diploma Program, Admissions } \\
\text { Policy and Admission Requirements }\end{array}$ & 11 & . & $\% 1 \cdots$ \\
\hline$\varepsilon$ & $\begin{array}{l}\text { Areas of Work for the Proposed Health Clubs } \\
\text { Management Diploma Program }\end{array}$ & 11 & . & $\% 1 \ldots$ \\
\hline
\end{tabular}




\begin{tabular}{l|l|l|l|l}
\hline$\bullet$ & $\begin{array}{l}\text { Methods of teaching and learning Diploma } \\
\text { program management of the proposed health } \\
\text { clubs }\end{array}$ & 11 & $\cdot$ & $\% 1 \ldots$ \\
\hline$\checkmark$ & $\begin{array}{l}\text { Ways to Evaluate the Proposed Health Clubs } \\
\text { Management Diploma Program }\end{array}$ & 11 & $\cdot$ & $\% 1 \cdots$ \\
\hline
\end{tabular}

The specific phrases for each axis were put forward and were presented to the experts for their opinion on the appropriateness of the phrases and their relevance to each axis.

Based on the opinions of the experts, the expressions obtained with a percentage of approval of $(75 \%)$ or more were accepted and a number of statements that were not considered suitable for the program's axes were excluded (5). Thus, Of the axes.

\section{Table (2) Number of statements for each axis of the proposed program axes}

\begin{tabular}{|c|c|c|}
\hline 3 & Program axes & Number of phrases in each axis \\
\hline 1 & $\begin{array}{l}\text { Objectives of the proposed management program for } \\
\text { health clubs }\end{array}$ & $\varepsilon$ \\
\hline \multirow[t]{4}{*}{ r } & $\begin{array}{l}\text { Targeted Learning Outcomes for the proposed } \\
\text { Health Clubs Management Diploma Program } \\
. \text { Knowledge and understanding }\end{array}$ & 0 \\
\hline & ب.Mental & 0 \\
\hline & جrofessional and practical skills & $\varepsilon$ \\
\hline & دGeneral and movable skills & $r$ \\
\hline$r$ & $\begin{array}{l}\text { Contents of the Proposed Health Clubs Management } \\
\text { Diploma Program, Admissions Policy and } \\
\text { Admission Requirements }\end{array}$ & $1 \leq$ \\
\hline$\varepsilon$ & $\begin{array}{l}\text { Areas of Work for the Proposed Health Clubs } \\
\text { Management Diploma Program }\end{array}$ & $r$ \\
\hline 0 & $\begin{array}{l}\text { Methods of teaching and learning Diploma program } \\
\text { management of the proposed health clubs }\end{array}$ & $1 \cdot$ \\
\hline 7 & $\begin{array}{l}\text { Ways to Evaluate the Proposed Health Clubs } \\
\text { Management Diploma Program }\end{array}$ & 7 \\
\hline \multicolumn{2}{|c|}{ Total number of statements } & $0 \leqslant$ \\
\hline
\end{tabular}

The researchers developed a three-pronged scale of responses to the questionnaire terms as follows:

(Suitable) and estimated at three degrees. - (Appropriate modification) and estimated at two levels .- (Not appropriate) and estimated at one level.

validity: The researchers used the validity of internal consistency to calculate the validity of the proposed program expressions by finding the correlation coefficient between each statement and the total degree of the axis represented by it. All the statements were statistically significant at 0.05 level, 6)

reliability : The researchers used the method of reliability of the alphacronbach method for the sub-axes and the total score. The values of the stability coefficient ranged between 0.655 and 0.711 on all axes of the proposed program, indicating that the axes have an acceptable degree of stability. 
View and discuss results:

Table (3) Frequency, estimated total, percentage and rank of the goals of the Diploma program of physical education and sports specialization of the management of health clubs. $(N=282)$

\begin{tabular}{|c|c|c|c|c|c|c|}
\hline \multirow[b]{2}{*}{$p$} & \multirow[b]{2}{*}{ Phrases } & \multicolumn{3}{|c|}{ Frequency } & \multirow{2}{*}{$\begin{array}{l}\text { Total } \\
\text { Estima } \\
\text { ted }\end{array}$} & \multirow{2}{*}{$\begin{array}{l}\text { Perce } \\
\text { ntage }\end{array}$} \\
\hline & & $\begin{array}{l}\text { Very } \\
\text { agreeable }\end{array}$ & $\begin{array}{l}\text { moderate } \\
\text { ly }\end{array}$ & $\begin{array}{l}\text { Not } \\
\text { agree }\end{array}$ & & \\
\hline 1 & $\begin{array}{l}\text { Understand the principles and principles of public } \\
\text { administration, sports management and management of } \\
\text { health clubs }\end{array}$ & Ylo & $\theta \wedge$ & 9 & $V V \cdot$ & $91, \cdot$ \\
\hline$r$ & $\begin{array}{l}\text { Recognition of the scientific bases and legal regulations } \\
\text { related to the establishment and establishment of health } \\
\text { clubs }\end{array}$ & rr. & $\Delta r$ & 1. & $V \vee \leq$ & 91,0 \\
\hline$r$ & $\begin{array}{l}\text { Using the continuous self-development of his personal } \\
\text { and professional skills }\end{array}$ & $1 \wedge \varepsilon$ & $\Lambda \mu$ & 10 & VTr & ᄉ५, \\
\hline$\varepsilon$ & $\begin{array}{l}\text { Recognition of the uses of modern technological } \\
\text { methods in professional and technical practices at the } \\
\text { health club }\end{array}$ & rrs & $r v$ & 11 & $\vee \wedge \vee$ & $9 \pi, \cdot$ \\
\hline
\end{tabular}

It is clear from Table (3) that the responses of the research sample on the terms of the first axis ranged between (93\% and 86.6\%). The researchers say that in order for the health club specialist to carry out his mission, And this requires that the opportunity be prepared through a program on scientific grounds with clear and specific objectives, and to have the opportunity to exploit all its capabilities and potentials, in order to achieve satisfactory results and fruitful.

Echevaria (2000), 14 (Carole Veir, 2003), 12 agree that the beneficiaries of the program should be involved in setting the objectives of the program that will help them to develop with the requirements of the new profession, and training in self-learning methods to achieve optimum work performance.

\section{Table (4) Frequency and Estimated Total and Percentage of Educational}

Results Targeted for Physical Education and Sports Diploma Program for the Management of Health Clubs. $(\mathrm{N}=282)$

\begin{tabular}{|c|c|c|c|c|c|c|}
\hline \multirow[b]{2}{*}{ p } & \multirow[b]{2}{*}{ Phrases } & \multicolumn{3}{|l|}{ Frequency } & \multirow{2}{*}{$\begin{array}{l}\text { Total } \\
\text { Estima } \\
\text { ted }\end{array}$} & \multirow{2}{*}{$\begin{array}{l}\text { Perce } \\
\text { ntage }\end{array}$} \\
\hline & & $\begin{array}{l}\text { Very } \\
\text { agreeable }\end{array}$ & $\begin{array}{l}\text { moderate } \\
\text { ly }\end{array}$ & $\begin{array}{l}\text { Not } \\
\text { agree }\end{array}$ & & \\
\hline & Knowledge and understanding & & & & & \\
\hline 1 & $\begin{array}{l}\text { Recognizes the scientific bases in the management of } \\
\text { health clubs }\end{array}$ & $r \cdot r$ & Vr & 1. & Vos & $\wedge 9,1$ \\
\hline r & $\begin{array}{l}\text { Identifies the problems related to supervising the } \\
\text { employees of the health club and how to overcome them } \\
\text { in the light of the information and possibilities available }\end{array}$ & Y10 & 09 & 11 & 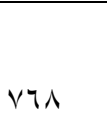 & $9 \cdot, \wedge$ \\
\hline$r$ & $\begin{array}{l}\text { shows the economic impact of work in the field of health } \\
\text { clubs on the founders and the general economy. }\end{array}$ & $r \cdot r$ & 70 & $1 \leqslant$ & vor & $\wedge 9, \cdot$ \\
\hline$\varepsilon$ & $\begin{array}{l}\text { Recognizes the legal aspects and social legislation } \\
\text { related to the establishment, establishment and }\end{array}$ & Y19 & 09 & $\varepsilon$ & $\vee \vee q$ & 94,1 \\
\hline
\end{tabular}




\begin{tabular}{|c|c|c|c|c|c|}
\hline management of health clubs. & & & & & \\
\hline $\begin{array}{l}\text { Determines the planning criteria for health clubs in light } \\
\text { of the objectives }\end{array}$ & ri. & r & 9 & V7o & $9 \cdot, \xi$ \\
\hline Mental skills & & & & & \\
\hline $\begin{array}{l}\text { Analyzes issues related to the management of health } \\
\text { clubs and arranges them in accordance with their } \\
\text { priorities }\end{array}$ & riv & $\leqslant 9$ & 17 & V70 & $9 \cdot, \varepsilon$ \\
\hline $\begin{array}{l}\text { summarizes the most important requirements of the } \\
\text { profession of the director of the health club, the } \\
\text { administrative club health and market activities and } \\
\text { programs of the health club }\end{array}$ & 19. & $\vee q$ & ir & $v \leq 1$ & $\Lambda \vee, T$ \\
\hline $\begin{array}{l}\text { Review the latest scientific researches in the field of } \\
\text { health clubs and analyze them }\end{array}$ & $r \leq$. & $\varepsilon$. & r & $\Lambda \cdot r$ & $9 \varepsilon, \wedge$ \\
\hline $\begin{array}{l}\text { Analyzes data and demonstrates strengths and } \\
\text { weaknesses }\end{array}$ & 199 & Vr & 11 & vor & $\wedge \wedge, q$ \\
\hline $\begin{array}{l}\text { Professional decision making in light of available } \\
\text { information }\end{array}$ & Tra & $\varepsilon q$ & $v$ & vAr & 94,7 \\
\hline Practical professional skills & & & & & \\
\hline $\begin{array}{l}\text { can communicate with some of the health clubs and } \\
\text { training through and with the help of the department }\end{array}$ & $r \leq r$ & $r \varepsilon$ & 7 & $\wedge \ldots$ & $9 \leqslant, 7$ \\
\hline $\begin{array}{l}\text { The theoretical information is applied in an applied form } \\
\text { in its training place }\end{array}$ & 191 & $\wedge$ & 1. & $V \leq 0$ & $\wedge \wedge, 1$ \\
\hline Write professional reports & YI & $\Delta \wedge$ & 14 & VTr & $9 \cdot, 1$ \\
\hline $\begin{array}{l}\text { Plans to market the health club, its programs and } \\
\text { activities well }\end{array}$ & r. & r & 9 & V7o & $q \cdot, \xi$ \\
\hline General and movable skills & & & & & \\
\hline $\begin{array}{l}\text { Utilizing modern tools and technologies in health club } \\
\text { management }\end{array}$ & IAr & $\wedge$ & 19 & VYV & 10,9 \\
\hline $\begin{array}{lccc}\text { Can implement human } & \text { resources } & \text { management } \\
\text { procedures and policies } & & \end{array}$ & $r \cdot 1$ & $v_{1}$ & 1. & voo & $\wedge 9, \mathrm{r}$ \\
\hline $\begin{array}{l}\text { Acquires effective communication skills at the health } \\
\text { club (target category - workers - administrators trainers }\end{array}$ & r.. & $\checkmark \cdot$ & ir & vor & $\wedge \wedge, q$ \\
\hline
\end{tabular}

It is clear from Table (4) that the responses of the research sample on the terms of the second axis ranged between $94.8 \%$ and $85.9 \%$. This is due to the need for the specialist to know many knowledge and concepts related to the field of health clubs that contribute to the formation of his knowledge structure, The frameworks in which a health club specialist can move through and enable him to practice his professional work. As well as developing his skills in analysis, excellence, evaluation, classification, conclusion and innovation in the light of the information and knowledge he has acquired as well as his ability to develop solutions to the problems encountered in the planning and implementation of health club programs. It is also necessary for workers in the health clubs to acquire behavioral patterns that make it able to deal with its employees As well 
as the need to develop its capabilities to use modern methods and methods of technology in the implementation of health programs, and the ability to record data, analysis and classification. Also confirms Mohammed Mohammed Alhamahmi, and Amin Anwar Kholi (2001) provides that physical education programs seeking to keep pace with scientific progress, which is characterized by the modern era, and therefore depend built on modern scientific, educational and social foundations so contribute to the needs of society and individuals cope with the educational philosophy of the community (9:37). The Standards of the Accreditation Council (COA, 2004) also refer to the ability to apply existing technology to professional practices separately and in integrated formats of professional practices. Examples of technology include reporting, slide programs, database management, presentations and graphics programs, Internet. (13:15)

Table (5) Frequency and estimated total and percentage on the third axis The content of the diploma program of physical education and sports specialization of the management of health clubs $(n=282)$

\begin{tabular}{|c|c|c|c|c|c|c|c|}
\hline \multirow[b]{2}{*}{ م } & \multirow{2}{*}{$\begin{array}{l}\text { Code and } \\
\text { Number }\end{array}$} & \multirow[b]{2}{*}{ Course } & \multicolumn{3}{|l|}{ Frequency } & \multirow{2}{*}{$\begin{array}{l}\text { Total } \\
\text { Estimated }\end{array}$} & \multirow[b]{2}{*}{ Percentage } \\
\hline & & & $\begin{array}{l}\text { Very } \\
\text { agreeable }\end{array}$ & moderately & $\begin{array}{l}\text { Not } \\
\text { agree }\end{array}$ & & \\
\hline 1. & p. & $\begin{array}{l}\text { Principles of Physical } \\
\text { Education }\end{array}$ & r) & $0 \leqslant$ & 9 & $V \vee \leq$ & 91,0 \\
\hline 2. & ن.ف ا • & $\begin{array}{l}\text { Measurement and } \\
\text { Evaluation in Physical } \\
\text { Education }\end{array}$ & r) & $0 \leqslant$ & 9 & $V \vee \varepsilon$ & 91,0 \\
\hline 3. & أ.ر 1 & $\begin{array}{l}\text { Scientific Management } \\
\text { Entrance }\end{array}$ & TrE & rv & 11 & VAV & qr,. \\
\hline 4. & أ.ر r & $\begin{array}{l}\text { Laws and Ethics of } \\
\text { dealing with customers } \\
\text { of health clubs }\end{array}$ & YI. & $v$. & r & VVY & $91, r$ \\
\hline 5. & أ.ر J & $\begin{array}{l}\text { History and } \\
\text { Development of Health } \\
\text { Clubs }\end{array}$ & TrT & 01 & $\wedge$ & $\vee \vee q$ & 94,1 \\
\hline 6. & أ.ر \& & $\begin{array}{l}\text { Strategic Planning of } \\
\text { the Health Club }\end{array}$ & TrE & $\leqslant 7$ & Ir & VVT & $91, \mathrm{~V}$ \\
\hline 7. & أ.ر & $\begin{array}{l}\text { Marketing of health } \\
\text { clubs and their } \\
\text { programs }\end{array}$ & $r \cdot V$ & דוד & 9 & VTY & $9 \cdot, 1$ \\
\hline 8. & أ.ر & $\begin{array}{l}\text { Contemporary Issues in } \\
\text { the Management of } \\
\text { Health Clubs }\end{array}$ & YI. & TV & 0 & 879 & $9 \cdot, 9$ \\
\hline 9. & أ.ر V. & $\begin{array}{l}\text { Competencies and } \\
\text { specifications of the } \\
\text { directors of health clubs }\end{array}$ & Y) & $\leq \wedge$ & 10 & $\vee \vee A$ & $9 \cdot, 1$ \\
\hline 10. & أ.ر 1 . & $\begin{array}{l}\text { Establishment of health } \\
\text { clubs }\end{array}$ & 119 & $\Lambda T$ & v & $V \leq 7$ & $\wedge \wedge, r$ \\
\hline 11. & أ. & $\begin{array}{l}\text { Public Relations Portal } \\
\text { for the Directors of } \\
\text { Health Clubs }\end{array}$ & $r \cdot \varepsilon$ & זד & 10 & vor & $\wedge 9,$. \\
\hline
\end{tabular}




\begin{tabular}{|c|c|c|c|c|c|c|c|}
\hline 12. & أ.ر · & $\begin{array}{ll}\begin{array}{l}\text { Organizing } \\
\text { competitions }\end{array} & \text { sports } \\
\end{array}$ & $r \cdot T$ & TV & 9 & V71 & $9 .,$. \\
\hline 13. & أ.ر 11 & $\begin{array}{l}\text { Management } \\
\text { seminars, conferences } \\
\text { and courses }\end{array}$ & 111 & 10 & 9 & $v \leqslant r$ & $\Lambda \vee, \Lambda$ \\
\hline 14. & أ.ر & $\begin{array}{l}\text { Management of training } \\
\text { programs for the } \\
\text { development of workers } \\
\text { in health clubs }\end{array}$ & $1 \wedge \varepsilon$ & $\wedge \varepsilon$ & $1 \varepsilon$ & VT & $\wedge \uparrow, \wedge$ \\
\hline
\end{tabular}

It is clear from Table (5) that the responses of the research sample on the terms of the third axis ranged between $93 \%$ and $86.8 \%$. The researchers believe that it is essential that the specialist recognize the general basis of management, the history and development of health clubs, As well as the laws and ethics that must be in place to deal with those who are hesitant. According to Muhammad Kamal Samanoudi 2001, when designing the program, many variables must be considered while building the program. The program should be associated with the organization's mission, Esters And the participation of target groups in programs in program planning, since programs can not be planned beyond the actual reality and needs of the target group of programs. $(8: 67,68)$

Table (6) Frequency and Estimated Total and Percentages on the Fourth Axis Fields of Work for Diploma Program of Physical Education and Sports Management of Health Clubs ( $N=282)$

\begin{tabular}{|c|c|c|c|c|c|c|}
\hline \multirow[b]{2}{*}{ b } & \multirow[b]{2}{*}{ Areas of work } & \multicolumn{3}{|l|}{ Frequency } & \multirow{2}{*}{$\begin{array}{l}\text { Total } \\
\text { Estimated }\end{array}$} & \multirow[b]{2}{*}{ Percentage } \\
\hline & & $\begin{array}{l}\text { Very } \\
\text { agreeable }\end{array}$ & moderately & $\begin{array}{l}\text { Not } \\
\text { agree }\end{array}$ & & \\
\hline 1 & Private health clubs & Y10 & ov & 1. & 879 & $9 \cdot, 9$ \\
\hline 2 & $\begin{array}{l}\text { Health Clubs in all sectors } \\
\text { (National - Private - Private) }\end{array}$ & rI. & ov & 10 & vo9 & $\wedge 9, \vee$ \\
\hline 3 & $\begin{array}{l}\text { Health clubs in hotels and } \\
\text { tourist villages }\end{array}$ & $r \ldots$ & VY & 1. & Vos & $\wedge 9,1$ \\
\hline
\end{tabular}

It is clear from Table (6) that the responses of the research sample on the terms of the fourth axis ranged between $(90.9 \%$ and $89.1 \%)$. The researchers believe that it is necessary to provide a specialist to work in health clubs with a high degree of efficiency in order to work in different sectors

Table (7) Frequency, estimated total and percentage, on the fifth axis "Teaching and learning methods" ( $n=282)$

\begin{tabular}{|c|c|c|c|c|c|c|}
\hline \multirow[b]{2}{*}{ r } & \multirow{2}{*}{$\begin{array}{lr}\text { Methods } & \text { of } \\
\text { Teaching } & \text { and } \\
\text { Learning } & \end{array}$} & \multicolumn{3}{|l|}{ Frequency } & \multirow{2}{*}{$\begin{array}{l}\text { Total } \\
\text { Estimated }\end{array}$} & \multirow[b]{2}{*}{ Percentage } \\
\hline & & $\begin{array}{l}\text { Very } \\
\text { agreeable }\end{array}$ & moderately & $\begin{array}{l}\text { Not } \\
\text { agree }\end{array}$ & & \\
\hline 1 & Lecture theory & $r \ldots$ & VY & 1. & Vos & $\wedge 9,1$ \\
\hline$r$ & Workshops & rI. & ov & 10 & 109 & $\wedge q, \vee$ \\
\hline r & $\begin{array}{ll}\text { Dialogue } & \text { and } \\
\text { discussion } & \end{array}$ & rio & ov & 1. & V79 & $9 \cdot, 9$ \\
\hline$\varepsilon$ & Seminars & 119 & $\wedge T$ & V & $V \leqslant 7$ & $\wedge \wedge, r$ \\
\hline 0 & Brainstorming & 111 & 10 & 9 & $V \leqslant r$ & $\wedge \vee, \wedge$ \\
\hline 7 & Self - learning & $1 \wedge \varepsilon$ & Ar & 10 & VTr & $\wedge \neg\rceil$, \\
\hline V & Educational bags & $1 \wedge \varepsilon$ & $\Lambda \varepsilon$ & $1 \leq$ & $V \Psi \varepsilon$ & $\wedge 7, \wedge$ \\
\hline
\end{tabular}




\begin{tabular}{|c|c|c|c|c|c|c|}
\hline$\wedge$ & E $\quad-\quad$ Learning & 194 & $\vee 9$ & 1. & $V \leqslant V$ & $\Lambda \wedge, r$ \\
\hline 9 & Distance education & $19 \pi$ & $\sqrt{11}$ & 11 & 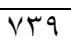 & $\lambda \vee, \varepsilon$ \\
\hline 1. & $\begin{array}{l}\text { Practical practical } \\
\text { performance }\end{array}$ & (1). & 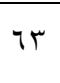 & 9 & V70 & $9 \cdot, \varepsilon$ \\
\hline
\end{tabular}

It is clear from Table (7) that the responses of the research sample on the terms of the fifth axis ranged between (90.9\% and 86.6\%). The researchers explained that these methods were suitable and logical for the diploma stage, which differs from the methods used in the first stage Where the different methods of performance in the diploma stage to allow a lot of space for the students to express their ideas and intellectual orientations within the framework of objectivity and democracy and benefit from the educational experiences of faculty

members. TAMER AHMAD ABDUL HAMEED 2014 refers to the strategies of teaching and learning from a quality perspective. The most important strategies to be applied are respectively, brainstorming, competitive learning, collaborative learning, question-asking strategy, working in small groups, Concept maps, guided exploration, structural learning, as well as performance in groups. (2: 73)

Table (8) Frequency, estimated total and percentages, on the sixth axis "Program Evaluation" ( $n=282)$

\begin{tabular}{|c|c|c|c|c|c|c|}
\hline \multirow[b]{2}{*}{ 5 } & \multirow[b]{2}{*}{ Methods of evaluation } & \multicolumn{3}{|l|}{ Frequency } & \multirow{2}{*}{$\begin{array}{l}\text { Total } \\
\text { Estimated }\end{array}$} & \multirow[b]{2}{*}{ Percentage } \\
\hline & & $\begin{array}{l}\text { Very } \\
\text { agreeable }\end{array}$ & moderately & $\begin{array}{l}\text { Not } \\
\text { agree }\end{array}$ & & \\
\hline 1 & Semesters & YII & $0 \wedge$ & 14 & VIY & $9 \cdot, 1$ \\
\hline$r$ & Case study & 191 & 11 & 1. & $V \leqslant 0$ & $\wedge \wedge, 1$ \\
\hline$r$ & Report on project & TIT & 00 & $1 \varepsilon$ & VTr & $q \cdot, r$ \\
\hline$\varepsilon$ & Mid - term test & $r \cdot T$ & $7 \varepsilon$ & IT & VOA & $\wedge 9,7$ \\
\hline 0 & End of semester test & YII & 71 & 1. & 179 & $9 \cdot, \varepsilon$ \\
\hline 7 & Application test & Y10 & 07 & 11 & VฯA & $9 \cdot, 1$ \\
\hline
\end{tabular}

It is clear from Table (8) that the responses of the research sample on the terms of the fourth axis ranged from $(90.8 \%$ and $88.1 \%)$. The two researchers explained that the diploma students are evaluated on an ongoing basis. The methods vary and vary between the assignments assigned to them The evaluation process should include not only the evaluation of the students but also the evaluation of the programs themselves in terms of their objectives and their relevance to the changes of the age and the needs of the community, As well as the calendar Study itself based on global standards for measuring performance.

According to Ameen Al-Khouly, Gamal El-Din El-Shafei 2000, the process of evaluation of programs works to achieve several purposes, the most important of which is the review of programs and courses to develop the aspects that need to be modified in the light of what has been achieved from educational purposes This is done through the general level of the student and is carried out from the perspective of "the speed or slow pace of implementation of units and learning 
purposes, the ease and difficulty of learning material, interesting and sequential material, the connection of content for educational purposes." (3: 153) Conclusions:

The objectives of the Diploma program for the management of health clubs were proposed and included (4) phrases, the second axis The objectives of the Diploma Program for the management of the proposed health clubs include (17) words, the third axis: the content of the proposed management program for the proposed health clubs, and (14) Teaching and learning methods (10) phrases, the sixth axis: Methods of evaluation Diploma of the management of the proposed health clubs and ensure (6) phrases

\section{Recommendations:}

1- Adopting the diploma program of management of health clubs from the competent bodies and applying the proposed program after adoption.

2 - Setting the criteria and conditions for joining the program of management of health clubs in light of the quality standards and labor market needs.

3 - Coordination between the Department of Sports Management and some major health clubs, in order to develop plans and policies that achieve integration and meet the requirements of development.

4 - Holding workshops in different faculties and specialties of beneficiaries of the proposed program for development, improvement and enhancement to meet the needs of the labor market.

\section{references:}

1-Ibrahim Shawqi (2003): Problems of professional preparation - Problems of students of the United Arab Emirates University - Department of Psychology at the Universities of Cairo and the United Arab Emirates, published in the Journal of Humanities and Social Sciences

2-Tamer Ahmed Abdel Hamid (2014): "Teaching and learning strategies in the light of the quality of basic education", PhD thesis, unpublished, Library of the Faculty of Physical Education for Boys, Helwan University

3. Sally Said Abdo (2014): "Evaluation of the Sports Management Program in Light of Some Ruling Standards and the Characteristics of the Graduate", unpublished PhD thesis, Faculty of Physical Education Library for Girls, Helwan University.

4. Shaimaa Mohamed Yahya: Effective management of the human element and its role in the quality of performance and satisfaction of beneficiaries in health clubs, 2012

5. Abdel Rahman Mohamed Tantawy Mohamed Terre: Proposed organizational structure for the management of health clubs in tourist villages, 2012 6. Emad El-Din Mostafa Abdel-Aal: "Assessment of the level of rehabilitation and preventive services in light of the organizational structure of health clubs", PhD thesis, 2014 
7. "The Challenges of Implementing Total Quality Standards in University Education", Special Issue, 7th International Conference, "Education at the Beginning of the Third Millennium: Quality - Availability - Lifelong Learning", Volume 3, Institute of Educational Studies, Cairo University.

8. Mohammad Kamal Al-Samanoudi (2001): Applications in Recreation and Leisure, Al-Fursan Press, Mansoura.

9. Mohammed Mohamed Al-Hamahmi and Amin Anwar Al-Khawali: Foundations of Building Sports Recreation Programs, Third Edition, Cairo, Dar Al-Fikr Al-Arabi, 2001.

10. Mohamed Mohanna Ibrahim Khattab: Interests of leisure clubs in leisure time, Master Thesis, Faculty of Physical Education for Boys, Helwan University,.

11. Heba Ahmed Bastawy Ahmed: Total Quality Management as an Introduction to the Development of Administrative Performance of Health Clubs in Alexandria Governorate, Flemming Athletic Education, Alexandria, 2013

12-Carole, Veir: A Staff Development in Service Training Packet based upon the Texas Teacher Appraisal. Paper presented at the Annual Meeting of the American Education Research Association; Chicago, 2003.

13-Council On Accreditation (2004) : Standards and Evaluative Criteria , For Baccalaureate Programs in Recreation Park Resources and leisure Services.

14-Echevaria: In Service Training Needs of Teachers and principals of elementary schools of Purto-Rico, 2000.

15-Glenna : The reluctance of members to continue training in health sports club, 2011

16-Tery\& Denise :Amultivariate exploratory study to examine and review regulatory obligations in health sports clubs, 2014. 